\title{
7
}

\section{Does Romania Have a Chance to Join the Innovation Driven Economy?}

\author{
Alexandru Borcea ${ }^{1}$ and Rosemari Fuica ${ }^{2}$ \\ ${ }^{1}$ Romanian Association for Electronic \& Software Industry, ARIES, \\ ${ }^{2}$ Association for Promoting Electronic Technology, APTE,
}

Romania

\section{Introduction}

After two decades of democracy and four and a half year joining the EU, Romania's economic performance is still lagging behind almost all EU member states. Overheating its economy two years before and one year after joining EU, with an average annual GDP growth of over $6 \%$, at the end of 2008, Romania was bitterly stroked by the world financial crisis. Unaccustomed with economic forecasts and foresights, low cohesion of its business environment, and lack of vision, Romania pasted the crisis in confusion and low self trust.

But crisis almost past away and Romania is still not finding its own way and its place in EU and the world economy. The well trained workforce of the country is used efficiently mainly by foreign organizations, or left the country. Real cooperation between research organizations, universities and industry, almost doesn't exist. With a traditional regional low trust in government and own trade and professional organizations, it will be hard for the Romanian companies to be competitive in the future.

And new challenges are rising at the horizon. The developed countries observed that innovation driven countries past much easier the crisis than followers and strengthen their research and innovation policies and programs. More than this, the BRIC countries, which are counting for almost the half of the world population, developed and put in place very ambitious programs which have to bring those countries in 2020 to the innovation driven economy. The "Europe 2020" and the Chinese development program, for the same time horizon, which have to create $60 \%$ of the 2020 Chinese GDP by innovation, are good examples of those challenges.

The concern about the chance of Romania and the measures to be taken to guide our country to the innovation driven economy is lasting from more than 15 years. The Romanian Association for Electronic and Software Industry - ARIES, and The Association for Promoting Electronic Technology - APTE made several surveys, studies, strategies and policy papers to support the innovation process and culture for the electronic and software industry of Romania.

As methodology we used, both for analysis and synthesis of the strategies and policy papers the model developed by Prof. Michael Porter. But in the surveys we used also questions which came from our members and stakeholders, which reflect their needs and aspirations too. For the level of trust, which we are considering to be a crucial factor for how to shape 
the policy papers, we used the recommended questionnaire by Steven Covey in his book "The speed of trust". We consider that the culture issue, particularly the culture of innovation, is all the time the crucial factor to make a study or a policy paper which could shake and move people ahead.

Our intention is to follow the entire value chain of the Romanian business environment and to reveal the most important factors which jeopardize our way to the innovation driven economy and to design a road map which have to overcome most of our challenges. The resulting documents are not used only for advocacy purposes, but also to develop new services to the membership, or to shape the existing ones to the changing needs of them.

For the moment we succeeded to analyze the national system of innovation, by gathering information on the trade legislation, rules, national and European programs, which are very influential and effective in our country, on research, IP, technology transfer and best practices from the entire world. Surveys we did mainly on the general data of our companies, human resources, cultural issues and the perception of our members regarding programs to be implemented or university curricula for engineering.

In the future we are intending to extend our research on more sophisticated issues like clustering, cooperation synergies and new cultural approaches. We hope that in the future we will be able to make a research frame which will allowed us to conduct at least annually the surveys, to reshape each year our strategy and services to the membership.

\section{Overall description of the Romanian economy}

Embraced by the European integration fever, and the opportunities offered by it, Romanian and foreign companies, especially those coming from European Union, massively invested in sales, production and R\&D capacities in the country. The business opportunities of the companies, domestic and foreign, overstressed the demand especially that related to the human resources. The human resources engaged in the industry rose almost three times, and the sophistication rose significantly especially in the foreign companies which have invested in Romania. Locations like Bucharest, Cluj Napoca and Timisoara were been considerate as cities with major lack of qualified human resources. The pressure of the demand raised the net wages of the high tech organizations, from about 400 Euros/month to almost 1.000 Euros/month. Even the number of graduates from the technical universities doubled in this period, 8.000 graduates/year, the number of university professors and the investment in university $R \& D$, do not raised in the same proportion. According to a survey made by ARIES and the "Politehnica" University of Bucharest, the content and quality of the university curricula are considered totally inadequate to the actual needs of the employers.

In accordance with the actual FDI rates and domestic new investments, the sophistication of the demand of human resources raised also significantly. Not only foreign MNC like Infineon, Continental, Microchip, Freescale and others invested in R\&D, but many spin offs from those companies multiplied the know how which people got during their employment or expats coming back to their homeland to exploit the experience they got abroad. All those investments raised the capacity of the country to participate in the European research Framework Program and in other international and domestic programs. Even if the Romanian participation in those programs is still modest, each year we encounter significant growth and improvement. 
A significant lag behind is registered still in open innovation and technology transfer. If in the most developed countries university innovation means over 50\% revenues, in Romania, technology transfer, spin offs and acquisition of innovative companies are almost inexistent. The Romanian universities and research centers do not passed a radical transformation to become real resource centers for human resources or new products for the market. Their research and innovation experience and know how of them are still missing and the trust of the business environment in their competences is also very low.

If we are taking into consideration that Israel is producing more than $45 \%$ of its GDP from innovation, and the 2020 horizon of China is to produce more than $60 \%$ of its GDP by innovation, we can imagine at which challenges are obliged the Romanian industry.

A significant lack of government services to support the competitiveness of the companies acting in the country and especially a low interest and appetite of the local governments to rise and support the local competitiveness is also an impediment for the self trust of the companies. Science and technology parks are totally missing, and the related support services of the governments, which abound in the developed countries, are also missing. For this reason, the clustering and their synergetic effects are in an incipient phased development.

However it has to be mentioned the program of the Ministry of Economy, Commerce and Business Environment to support the internationalization of the Romanian companies by trade missions and participation at international fairs of more than 500 companies per year, and the branding of different industries, which really has a real impact in contracting on foreign markets and on the image and trust in our country. In the last three years of crisis the export of our country rose over $50 \%$, in contrast to the domestic market which diminished more than $15 \%$.

A similar important vector for the competitiveness of the Romanian companies, during the integration fever, was also the significant growth of the internal market, which became four times larger as before this process, assuring more market and product expertise for the emerging domestic companies and the size of the FDIs. A significant importance of this extension was the public and private investment in the information and knowledge society.

2009 started with the financial crisis, strongly moderating the explosive expansion of the Romanian companies. Companies like Siemens and Alcatel Lucent diminished significantly their operation in Romania. Recently, Nokia closed its production facility in our country. All MNC which operate in our country significantly diminished their expenses, beginning with promotion and ending with the operational ones. Luxurious headquarters are not anymore a fashion and a significant number of employees had to change their job.

Even if the Romanian companies do not reported significant drawbacks, they had to reduce their manpower or to freeze it at the level before the crisis. A large number of SMEs, especially micro enterprises closed the doors. Even if they are not employing a significant number of human resources, the signal given by them was very negative, especially for the young entrepreneurs. However, in full period of crisis, a number of companies, especially the innovative ones, reported significant growth and increase of employee's number.

Despite the strong negative effects, the crisis revealed that the old chip qualified labor offer of Romania, in the close neighborhood of Western Europe, is not anymore competitive and a new approach focused on innovation is the only reliable and lasting solution of any company acting in our country. 


\section{Chalanges and dificulties}

\subsection{Globalization}

After a decade of the twenty first century the entire world face unprecedented challenges of his history. Traditional and emergent or modern cultures of the entire world are fertilizing and influencing each other, creating by synergetic effects new cultures, approaches and thinking stiles. Doe to the modern transportation and communication means, people and cultures are in permanent contact in real time. Effectively, perception and understanding distortions are coming from cultural and thinking stiles differences of the different actors of the world. The internet and other communication means, included people all over the world, not far away isolated, in the world communication concert.

Surely, the thinking and the decision making stile or responsibility assuming and the competitiveness of nations are strongly influenced by the globalization. If today we are speaking about regional, national or transnational competitiveness like European Union, North America or Far East, surely, in several decades we will speak about global competitiveness of the communities as vectors of world development and stability.

But globalization has also quantitative and structural effects which, in the near future, will strongly influence the quality of our life. In less than two or three decades, billions of people will be integrated in the innovation driven economy, and billions of people around the world will work and think in a global knowledge environment. If today we are speaking about a targeted 3\% of the GDP, the biggest part of the innovation and knowledge in the developed countries, probably in few decades, those activities will count over $50 \%$ of the world GDP. Generation and valuation of knowledge will be the most important activity of the world.

The most important challenges of the globalization are linked to the individual readiness to understand globalization phenomenon and structures, to shape measures and take decisions, and to have the capacity of analysis, synthesis, integration and implementation, in accordance with the needs and cultures of the national, regional and professional communities which they are representing. Also the organic structure of the communities and the rise and speed up of their analytic, synthetic and harmonization capacity will be in the near future crucial because pioneering will surpass the follower's strategy.

\subsection{National system of innovation}

\subsubsection{Innovation}

Innovation was, is and will be the universal vector of development and competitiveness of the human communities, from the beginning of history to the end of the human kind. Communication and information in a broader sense, and the related technologies, were been and still are the innovation drivers in the entire world. From the beginning of history and today, there are no groups of people or communities to impose them self in front of others without innovation. From the abstracting, formalization, processing, diffusion and infusion of information, to the modern technologies, everything is related to innovation. This essential innovation, brought people much closer to each other, developing synergetic effects for the development of the social structures, communities and welfare, which permitted the innovation for other common needs.

Even if it appear to be exaggerated, in the modern sense of the notion's acceptance, the support and diffusion systems of innovation are present also at the early human societies, 
but especially at the early states, by standards, rules and laws, later on by techniques and technologies. As more powerful was the innovation, as larger and more lasting was the society which made it. That type of innovation for the development of societies and communities, by specialized institutions for security, regulation and law, locally or central, are mutually recognized by any member of the community, accepted as universal standards.

The narrow sense of innovation, even if it is totally dependent on the broader sense, means mostly technology and process innovation, more recently also business model innovation, and very recently, coming back to the roots, social innovation. The most important components of the innovation, analyzed by most countries, and on which are concentrated the majority of policies, are education of human resources and R\&D.

We are willing to stress on the crucial importance of the innovation culture and attitude, which make the difference between nations.

The most important challenges of the technology, process and business model innovation, of any nation, are the financing of the human resources education, the R\&D activities and infrastructure, and the development and assimilation of new standards. Also challenges are related to the access to the information, diffusion and communication of information, intellectual property right, and the increase of the learning capacity of people during there entire lifecycle. If in the twenty century, government responsibility on innovation was mainly in the most developed nations, today, almost al governments are dealing with this issue because it became a life or death problem. In less than two decades, half of the people of the world will live in an innovation driven economy. And social innovation and culture of innovation will become crucial to support national or community global competitiveness.

If in the previous subchapters we describe the challenges in a general sense, because they are common for any nation, in the following subchapters we will refer more specific to our country.

\subsubsection{Education}

The Romanian university education is based on a French German model from the beginning of the twenty century, largely accepted and implemented by many countries from central and Eastern Europe. It is a model which brought outstanding outcomes supporting the modernization of this part of Europe. The competitiveness of its graduates was been worldwide recognized during the last century, and still used as fresh and educated human resources in the most developed countries. Several scientist from this region were been excellent researchers recognized in the entire world, and even Nobel Prize awarded, including Romanians. Examples as Henry Coanda, which made in France the first jet propulsion airplane of the world, and Prof. Gheorghe Samachisa which developed several patents for the flash memory, or Prof. Gheorghe Palade in California which was awarded with Nobel Prize for his contribution to the physics are only few of the outstanding Romanian scientist recognized worldwide. And many others, less known are enriching the human knowledge heritage in our country and worldwide.

But the university education system was not reformed from about 70 years. Doe to the old and strong organizational culture, it was almost impossible to reform anything in the university educational system. Not even the Bolognia Declaration adoption, or any other type of reform do not succeeded. In general, any change came up against with hostility. 
Even if the entire world is concerned about the life long learning, and the European Commission released significant funds for it through numerous programs, the corresponding curricular development are very poor at the Romanian universities.

If in the first decade after the revolution this approach do not harm, because the entire Romanian economy dropped over $50 \%$ and nobody cared about, in the first decade of the twenty first century, the industry began to rise rapidly, benefiting from significant foreign and domestic investments, the tensions between the business and university environments rose significantly. The communication between the two environments is relatively poor doe to the lake of associative structures. The exchange of experiences, content and good practices are poor and mainly based on interpersonal communication and not on communication between communities which are caring about each other.

First 2004, ARIES, The Romanian Association for Electronic and Software Industry, a trade professional organization, articulated the first innovation related strategy of the industry, university education and research included. Later on was funded the EPETRAN association of the electronic faculties of Romania, which is a forum of best practice sharing and communication with the industry. This initiatives and the fundation of the Export Council and more recently the National Competitiveness Council, where university, industry and public bodies are gathering discussing about the future developments and cooperation are real hopes of our country for its future competitiveness and community cohesion. Also very encouraging is the recent Employers Commission of ARACIS, the national university accreditation body of Romania, which comprise professional, trade professional and companies, concerned about the new European standards of accreditation.

If in the last decade of the twenty century and the first decade of the twenty first century, the main preoccupation of the Romanian universities was the assimilation of the triple size number of students, by enlarging the existing old universities and new universities, the next decade, the most important thing to be solved, will be the adaptation and matching of the university curricula to the real needs of the stakeholders and the development of the competitive research capabilities to support the national innovation effort.

The previous strategy, to raise the number of students and graduates was adequate for the business model based on chip labor cost. Entering the European Union, the business opportunities diversified and sophisticated very much, the old model beginning to show its limits. Companies which came to Romania several years ago for the educated chip labor cost are leaving more and more our country, and more and more domestic and foreign companies are investing and orienting toward innovation.

The most important challenges related to the human resources competitiveness and the sustainable curricular structures are determined by the structure of the professional organizations of the two environments, the quality and competitiveness of their content, the intensity and quality of their cooperation and trust and synergy between them. The introduction of a demand based funding of the public universities and faculties will motivate surely the opening of the universities to the business environment, which will drastically lower the actual conservative behavior. Also imposing evaluation criterions of the public universities related to the post university curricula for life long learning, to the research outcomes to support the national innovation and cooperation for knowledge and best practice sharing with the business environment will strengthen the interest of both parts to cooperate in their benefit and the trust which have to speed up their efficiency and 
reputation. Nevertheless a significant shift in attitude and culture related to the new world tendencies will be the key to success.

\subsubsection{R \& D}

Before the First World War, we can not speak about a competitive Romanian R\&D, even if the second industrial revolution already consecrated the universities as main vector of knowledge and innovation for the new competitive industries of US and Germany. Between the two World Wars, on the base of the German model, the university research is developed, mainly for the natural sciences and the first state owned foundations for research funding appears. Still, most of the Romanian scientist distinguishes oneself in the developed countries like France, Germany and UK.

After the Second World War, especially in the sixtieth and seventieth, were been funded very numerous technology research institutes, based on the Soviet model, very similar to the German one. The major differences between the German and the Soviet model was the strict political control of the hierarchy of the institutes, not all the time based on competences, a strict isolation from the university research and from each other, and an unnatural command of the state. In contrast, the German model means national foundations controlling individual institutes linked in a network and strongly related to the needs of the stakeholders and related to the university research. The university research was strongly diminished and restricted. The disjunction between universities and research institutes brought different evaluation standards and equivalents. Simple researcher was equivalent with university assistant, Principal Researcher III with lecturer which had to have also a doctoral degree and Principal Researcher I, equivalent with university professor, even if the first do not had to prove didactical activities. Those differences implied, during the time, excessive over employment, reduction of interest for innovation and focus on marginal themes and missions, implying a very low efficiency of innovation; too many efforts for insignificant outcomes.

The quasi general collapse of the Romanian industry in the first five years of democracy, the diminishing of the GDP with over $50 \%$ and the general confusion, characterizing that period, implied a systematic lowering of the government research funds for more than ten years. The number of researcher drastically diminished, several research institutes were been sold (privatized) especially for real estate interests and many researchers emigrated to US and other developed countries, mainly in Europe, or reoriented them self toward universities, private companies and other activities. The patenting activity is also diminishing significantly in that period.

At the beginning of the twenty first century, the first university research oriented programs was launched. Also the first sophisticated and innovation driven public procurement appears mainly in the field of information and knowledge society, implying Romanian workforce for their development. The constant positive growth of the Romanian economy and the European integration perspective in 2007 brought significant resources to the Romanian budget. The public research funds rose in that period from $0.1 \%$ of the GDP to almost $0.8 \%$ in 2008 . Also the share of the university research reached $70 \%$ of all public research funds. Unfortunately, the crisis stroke bitterly our country and the R\&D public fund dropped again to around $0.2 \%$ of the GDP. In compensation, the Romanian participation in the European Framework Programs rose, and the first innovation driven projects in the frame of the Structural Funds appears, supporting the competitiveness of the Romanian economy and of the companies. 
Unfortunately not even this flourishing period, which lasted five years, do not brought significant structural changes to Romanian R\&D. The R\&D outcomes, both from universities and research center network, are still not valuated by technology transfer, spin offs or on the IP market.

In this very moment, The National Agency for Science, Technology and Innovation, is the main public financing institution of the Romanian $R \& D$. The organization is leaded from the beginning by people coming from the old research institutes and from the universities, with insufficient knowledge and low commitment to the real needs of the emerging Romanian industry or other stakeholders. Their constant conservative attitude to preserve the survival, interests and the former "status quo" of these organizations, delay the reform. The cooperation with the business environment is almost inexistent. In comparison with ARACIS, the national body for higher education accreditation and other government and nongovernmental organizations, this one do not expressed any interest for the cooperation with the business environment or other stakeholders to improve the situation.

It have also to mention that the business environment don't was really interested about the outcomes of the Romanian research, being focused on the low cost labor opportunity which is not requiring too much sophistication or innovation. First in the last two years, doe to the rise of the wages and lower interest for chip labor cost in this region, companies began to switch for more innovation and IP development.

The main challenges for the Romanian R\&D are related to structural changes, attitudes and overall and organizational culture and behavior. So long as the stakeholders, companies, local authorities and government organizations interested in sophisticated public acquisitions, do not have the authority to say anything for the structure and destination of the research funds, and can't step in anyhow for the evaluation and attribution methods of the funds, a significant change or improvement are not to be expected. The link of the R\&D activity with the innovation support infrastructure, based on performance criterions is essential to ensure the efficient valuation of its outcomes.

\subsubsection{The innovation support infrastructure}

Even if the second industrial revolution is strongly related to $R \& D$, research were been made mainly in own research laboratories by vertical integration or by close cooperation with the university environment. The third industrial revolution brought new actors like SMEs, and new attitudes and business models like specialized R\&D companies and institutions and externalization of those activities to specialized organizations. Based on the US experience and success, after the Second World War, by its massive investments in military R\&D with extensions through spin offs and technology transfer to civil applications, all developed countries, and recently almost all states of the world, implied them self directly more and more to support the national competitiveness by public financing of the R\&D activities. Missis Chancellor, Angela Merkel, at the opening ceremony of CeBIT 2010, sad that Germany will spend in that year 3\% of its GDP for R\&D. All the states from the world are currently in an unprecedented competition to find the required funds to support directly the national effort for R\&D.

But very soon, everybody stated that this financing is not enough if they are not putting other efforts to support the speed up of the rapid valuation on the market of the R\&D activities' outcomes by supporting innovation. From the early fifties of the twenties century, US begun to build with public funds and public private partnership the cohesion and 
synergetic entities and clustering services like science and technology parks, business incubators and related support services for mach making, internationalization, technology transfer, IP and many others. The Silicon Valley initiative around the Stanford University demonstrated its viability and sustainability over the time. Its success inspired and still is inspiring the entire world.

By multiplying the success of Silicon Valley in many other states, the US created a strong network nationwide, which was enriched later on with other networks of technology transfer services, national laboratories and consulting services. Also private fund were been attracted and new institutes were been created to facilitate the diffusion of knowledge, new business foundation, and externalization of studies and specific strategies.

During its development, by assuming new functions and missions, the European Union developed also such networks like Enterprise Europe Network or funds to support common strategies and to facilitate synergies and clustering. Compared with US, the EU is focusing mainly on know how transfer, knowledge and best practice diffusion and valuation of the R\&D outcomes in the frame of the Union. The national initiatives could be supported by structural funds or they could be the responsibility of the national governments. Both, US and EU created independent specialized institutions like National Science Foundation and European Innovation Institute.

Unfortunately, out of several Romanian organizations involved in several European support programs, Romania is not excelling at this chapter too. Except of several enthusiasts, which have also European experience, the National Science, Technology and Innovation Agency's program turned out mostly in real estate business as real support of the Romanian innovation.

The main challenges of the Romanian innovation support infrastructure are related to the public private partnership, finance of the national research institutes or laboratories, financing facilitation, support services and business ethics including cultural and attitude shift toward the world best practices. At national level those issues are almost unknown. Identification of the needs related to R\&D and innovation, in public private partnership, and design and financing of the corresponding services in accordance with the local needs and conditions could support in the near future the local and national innovation and competitiveness.

\subsubsection{Culture and cohesion issues}

In my country business ethics is a foreign notion. Corporate social responsibility means mainly a responsibility related to employees and is mandatory by law. Company is a money producing machine and if it is possible, as easiest could be. Competition means a brutal fight against it. Quality is good if you need a label on it. Cooperation has to be avoided as possible. Community is very important if they could give money. And the good examples could go on.

Several years ago, speaking to a German deputy in the European Parliament, I was amazed by his reaction at my question about the concern of this Parliament on business ethics. His face expressed likes "what the hell is this". As fresh graduate of a special training on business ethics at George Washington University, I was sincerely surprised about his reaction. But I past over and I never were been surprised when somebody do not understand what about I'm speaking. At that occasion I learned that I have not to be surprised when other people are thinking otherwise as my self, but I have to make an effort to understand what they really meant. 
In general, if people would perform they have to get trust from others. Other way they remain isolated and the speed of growth is lowered by a factor dependant on trust. Trust means not only competences but also common feelings in a common space of language and culture. As higher the trust is and as stronger the empathy between each other, so better and higher is the efficiency between individuals, organizations and communities and the benefits are in the same proportion. Each individual from out of seven billion people in the world are thinking differently, but they have common tools like language and culture to understand and synergize each other.

Leading more than hundred Romanian trade missions abroad, I learned that before to make any step forward you have to understand the culture of your counterpart and to offer something which is valued within his culture. And your work is never ending because different people have different culture and different communities have different culture. Taking into account these things and consulting our membership, I observed that the efficiency of our delegation rose from event to event.

For example Germans in Europe have a very strong culture. They are very confident to each other, but if somebody is coming from a culture they do not understand they begin to be very mindful. There culture is based on common unwritten standards which are taught as young children in a common sense. For people whom are growing up in this culture, it is very unusual to understand somebody more relaxed and much more flexible in interpreting things and thoughts.

Romania is located in a region with a more relaxed behavior and less formalized culture with a low community cohesion. People are more own centered as community centered. But they want to be included in the larger concert of the world. They want to be trusted, they want to be efficient and innovative and they want to be accepted as they are. Everything is O.K., but for the last whish they have to strive bitterly.

The main challenges for the Romanian people are the big effort to understand what really is valued in the culture of others, and radically change their own culture and attitude. They have to understand the culture of the larger community of innovators or any other community they think to be part and to change attitude to shall more empathy and to have more engagement towards that communities. As any other culture, for sure, the Romanians have also values which could be valued within others culture and they have to strive for it. If they could be proud of their nation's heritage they will be able to conquer other's heart.

\section{Conclusions}

Several years ago I participated at a European conference on R\&D and innovation. Presenting the overall situation of this issue, a lady from DG research told to the audience of the conference that Romania and two other countries of the union are not striving enough for their competitiveness and they are "no chance lands". Even if I understood what she meant because she gave facts and figures compared to the other countries outcomes, being Romanian, I was very frustrated. I'm not blaming her because she told this before a large international audience, because I had the feeling that she was very honest, but I still not feeling good when I remember about this case. This event was for me the determination to understand really the situation, and if it is possible to contribute to my nations improvement. It was also the moment to start my research and to find solutions for my nation. 
I decided to be not scared or subjugated by this judgment but to be honest and straight on, to be able to have clear mind and clear judgment for the best recommendations and consulting I can make, first to the community of my association's members, and secondly to the Export Promotion Council and the National Council for Competitiveness. The same approach I used to improve the national and European quality standards of the national body for higher education accreditation ARACIS, and the funding body of the Romanian higher education research UEFISCDI. I already developed five policy papers in Romanian, of which content I used in this article.

From all challenges from the end of each chapter and subchapter I believe that the most important is about culture and attitudes. I already told to the reviewers from the World Bank on the performance of the National Agency for Research, Technology and Innovation, that doesn't make sense to raise the research funds before structural, cultural and attitude change, in accordance with the real needs and challenges of the stakeholders and the larger community of our nation, are not put in place. I'm also deeply convinced that those changes have to be made inside the beneficiary organizations, private or public. Financing have to come after competence and efficiency are proved.

Citing Peter Drucker who sad that the most important thing of our recent history is not the internet, or any other technology, but that people are less and less dependent and more and more have the opportunity to chose, and for the first time in the history, tremendous number of people, which rapidly growth, will lead them self, I understand that as people are getting more independent from each other, as much they have to care about their communities. Starting from this point I strongly believe that a concerted and harmonized triple helix public private partnership for any major concern of our nation, have to be put in place. Not only one part is responsible for what is happening among the community members or with the community as a whole, but everybody.

However, I'm strongly confident that solving these fundamental problems, it will be piece of cake to get the right solutions for any challenges mentioned by this article.

Yes for sure, Romania has a chance to join the innovation driven economy. Romania have to find his way among the most developed countries of the world, but he have to play his role, to be confident in him self and to get the trust of others.

\subsection{Empirical data - entrepreneurial spirit within ELAN project participants}

In the Global Innovation Performance 2009 report, Romania RANKS 61st. Also in Total Entrepreneurial Activity Ranked by Country, Romania has $4.3 \%$, compared to world average of $10,6 \% 1$. Also Romania ranks 5 th lowest in the world in terms of feeling that hard work brings adequate returns, ranking lower than the Eastern European average, lowest in the world. ${ }^{2}$

ELAN projects's main objective is to promote entrepreneurship in Romanian electronics industry, the electronics packaging education, and technological transfer, to offer

\footnotetext{
${ }_{1}$ 2nd report on Entrepreneurial Activities in Romania: executive summary for the year 2008, Total Entrepreneurial Activity Ranked by Country - TEA by Country Measures Entrepreneurial Activity as a Percent of GDP.

${ }^{2}$ Gallup World Poll , January 2011
} 
technological and technical support for innovative SMEs, in order to compensate the small entrepreneurs number ( $\sim 50 \%$ of the European average).

In this context, data collected during the implementation of the strategic project "Promoting the entrepreneurial spirit within the Romanian electronics industry", co-financed by European Social Fund (ESF), can give us an idea about the entrepreneurial spirit of the participants. 3628 participants to the campaign for promoting the entrepreneurial spirit "Be an entrepreneur!" answered the question: "Are you an entrepreneur?"

1. Never thought to

2. No, I thought to, made some steps and renounced

3. No, but I am thinking to a business

4. Yes, I am on the way to start a business

5. Yes, I have started or undertaken a business in the last 3 years, and it is alive

6. Yes, I have started or undertaken a business more then 3 years ago and it is alive

7. No, I started some time ago a business, but now I am not anymore an entrepreneur

\begin{tabular}{|c|c|c|c|c|}
\hline & ELAN participants Statistics & Total & Female & Male \\
\hline & Total & 3628 & 1268 & 2360 \\
\hline Education & Top of Form & & & \\
\hline level & Lower SecondaryBottom of Form & 91 & 11 & 80 \\
\hline & Top of Form & & & \\
\hline & Arts and Trade SchoolBottom of Form & 39 & 7 & 32 \\
\hline & Post Arts and Trade Schools & 18 & 3 & 15 \\
\hline & Top of Form & & & \\
\hline & Lower cycle of HighschoolBottom of Form & 576 & 226 & 350 \\
\hline & Upper secondary school & 1434 & 456 & 978 \\
\hline & Post Uper Secondary & 62 & 22 & 40 \\
\hline & Bachelor & 1038 & 390 & 648 \\
\hline & Master of science & 284 & 130 & 154 \\
\hline & $\mathrm{PhD}$ & 79 & 23 & 56 \\
\hline & Post PhD & 7 & 0 & 7 \\
\hline Age & $15-24$ & 2289 & 731 & 1558 \\
\hline & $25-44$ & 871 & 359 & 512 \\
\hline & $45-54$ & 298 & 119 & 179 \\
\hline & $55-64$ & 159 & 57 & 102 \\
\hline & over 64 & 13 & 2 & 11 \\
\hline Labor & inactives & 2086 & 691 & 1395 \\
\hline market & Entrepreneurs & 112 & 26 & 86 \\
\hline status & Self-employment & 76 & 16 & 60 \\
\hline & Members of an agricultural / cooperative & 2 & 2 & 0 \\
\hline & Employees & 1351 & 533 & 818 \\
\hline & Unemployed including unregistered unemployed persons & & & \\
\hline & Bottom of Form & 1 & 0 & 1 \\
\hline Residence & urban & 3156 & 1082 & 2074 \\
\hline & rural & 472 & 186 & 286 \\
\hline
\end{tabular}

Table 1. Participants grouped by gender, educational level, age, labor market status, place of residence. 


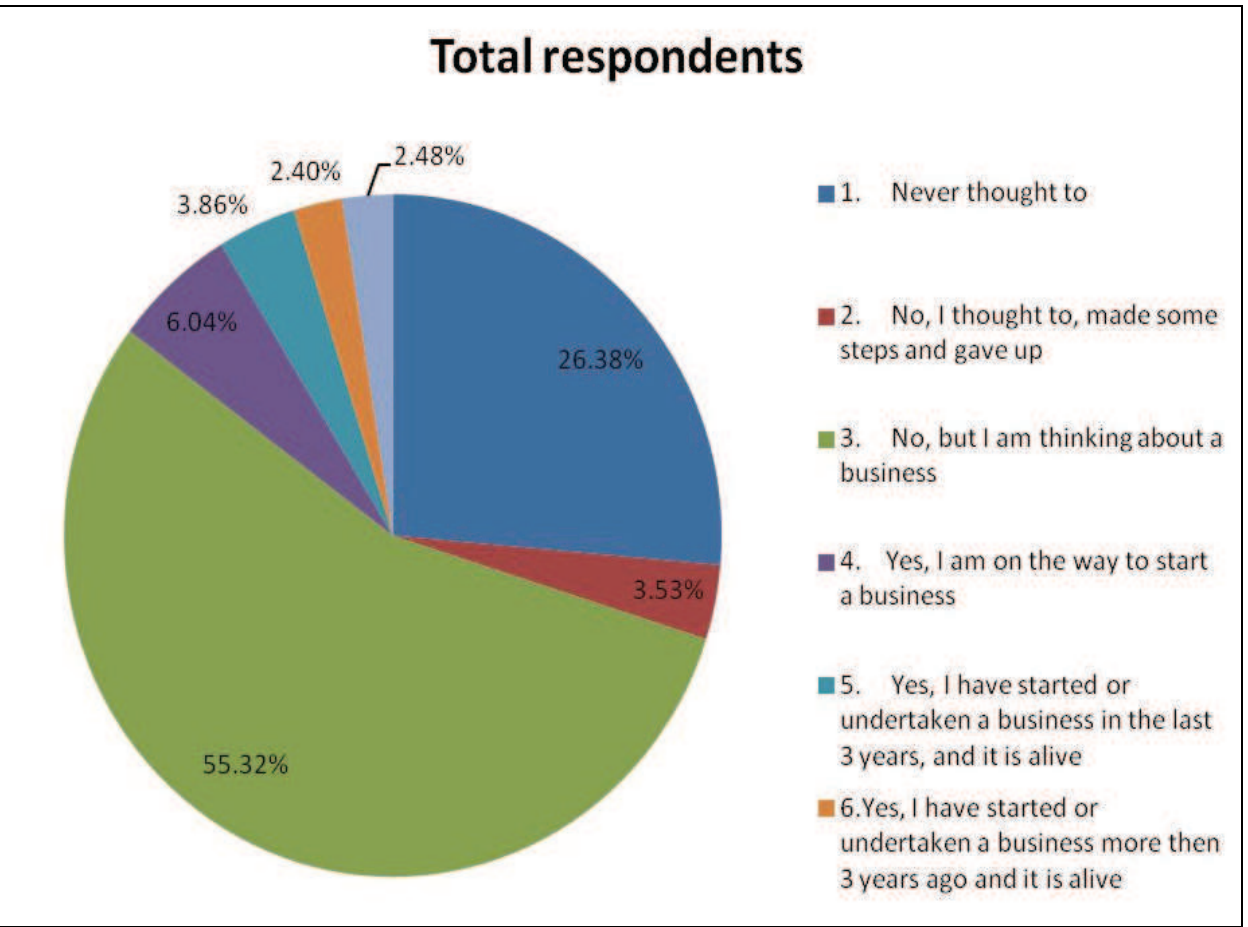

Fig. 1. Entrepreneurial spirit within ELAN project participants

Out of $100 \%, 26 \%$ never thought to a business, $3.53 \%$ thought to a business, made some steps and renounced, $55.32 \%$ are thinking to a business, $6.04 \%$ are on the way to start a business, 3.86\% have started or undertaken a business in the last 3 years, and it is alive, $2.40 \%$ started or undertaken a business more then 3 years ago and it is alive, and $2.48 \%$ started some time ago a business, but now I they are not anymore an entrepreneur .

Male participants have higher entrepreneurial spirit compared to female participants $76.78 \%$ /23.21\%.

There is a difference between male and female participants for those who:

- $\quad$ never thought about a business $23.77 \%$ / 31.23\%;

- $\quad$ are on the way to start a business $7.29 \% / 3.71 \%$;

- $\quad$ started or have undertaken a business in the last 3 years and it is alive $4.11 \% / 3.39 \%$;

- have started or undertaken a business more then 3 years ago and it is alive $2.54 \% / 1.42 \%$.

The difference is less significant between male and female participants for those who:

- thought about a business, made some steps and gave up 3.56\%/3.47\%,

- are thinking about a business $55.81 \% / 54.42 \%$,

- $\quad$ started some time ago a business, but now are not anymore an entrepreneur $2.54 \% / 2.34 \%$.

Entrepreneurial spirit is higher among highly skilled professionals (Post Arts and Trade Schools - 16,67\%, PhD - 16,46, Post PhD -14,29) 


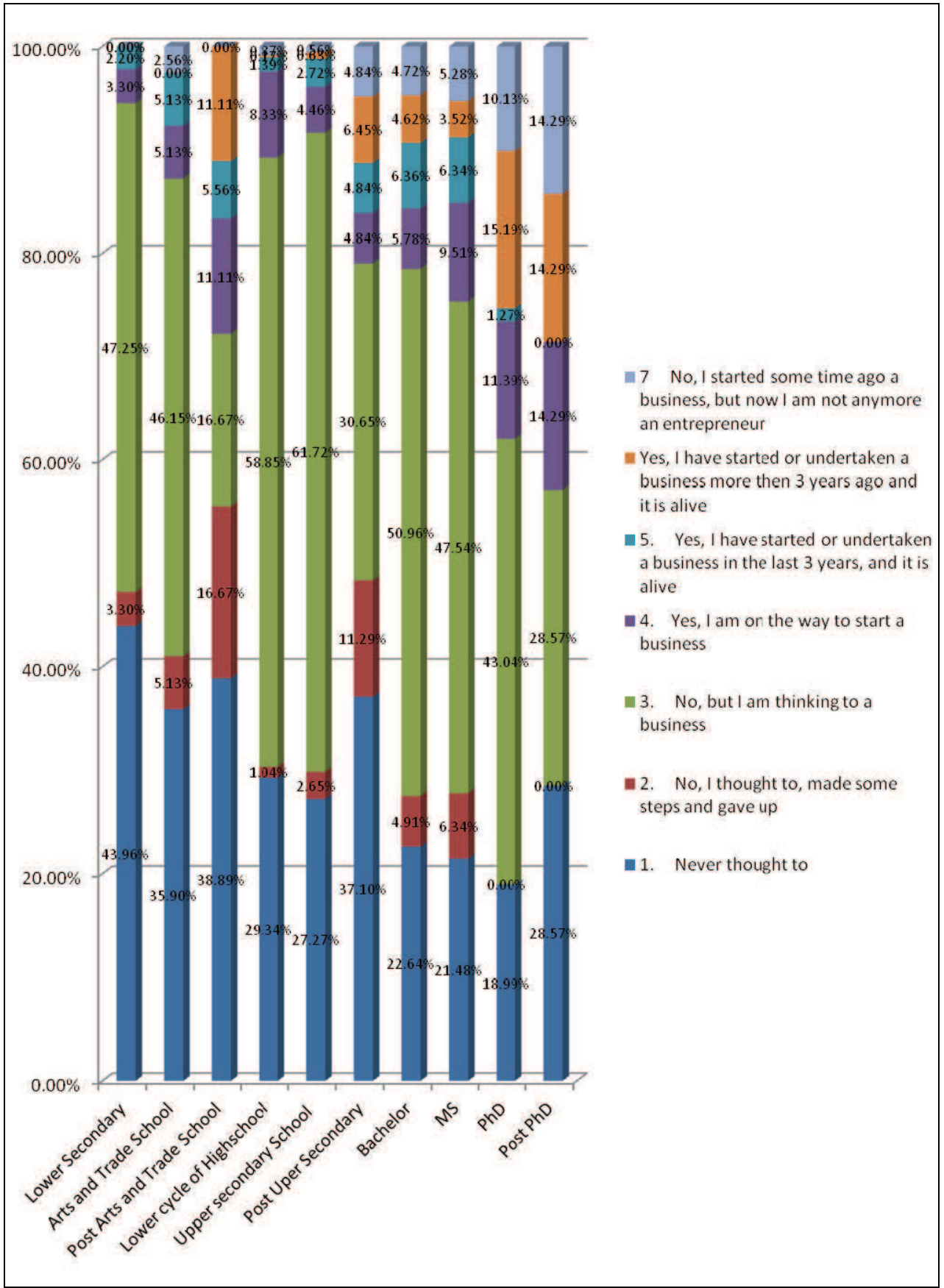

Fig. 2. Elan participant's entrepreneurial spirit by education 


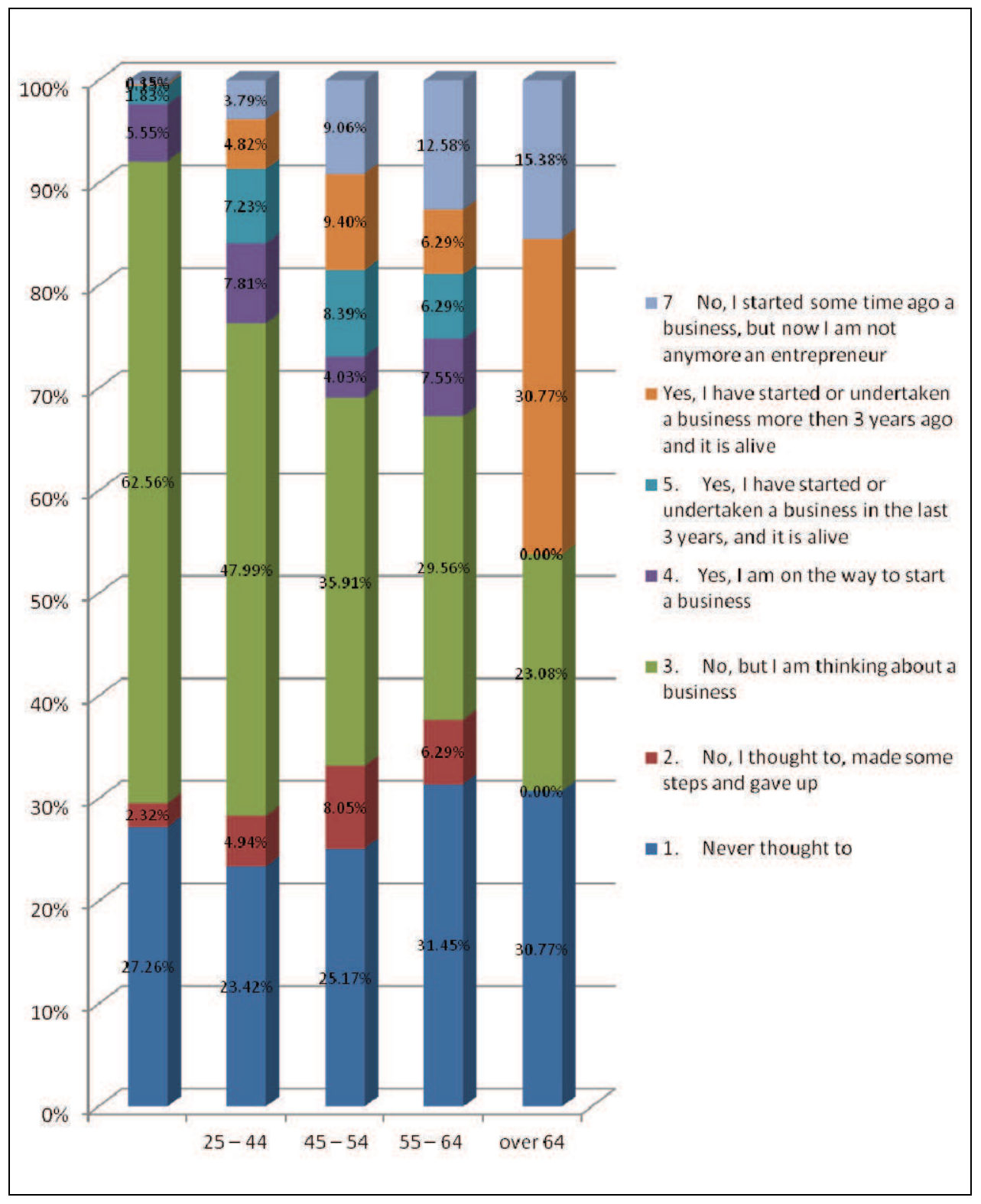

Fig. 3. Elan participant's entrepreneurial spirit by age

Entrepreneurs are not 'born'....rather they 'become' through the experiences of their lives. 


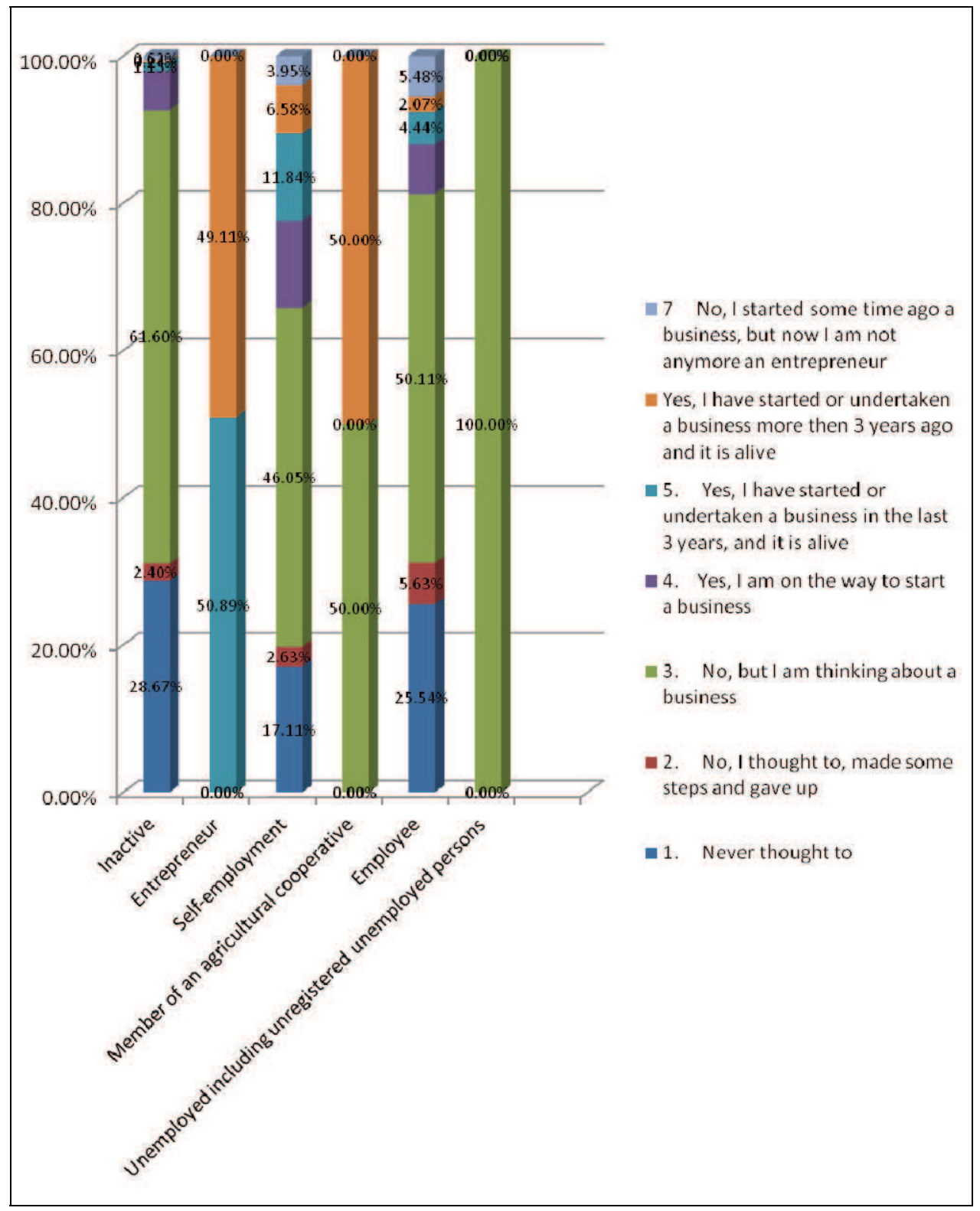

Fig. 4. Elan participant's entrepreneurial spirit by labor market status 


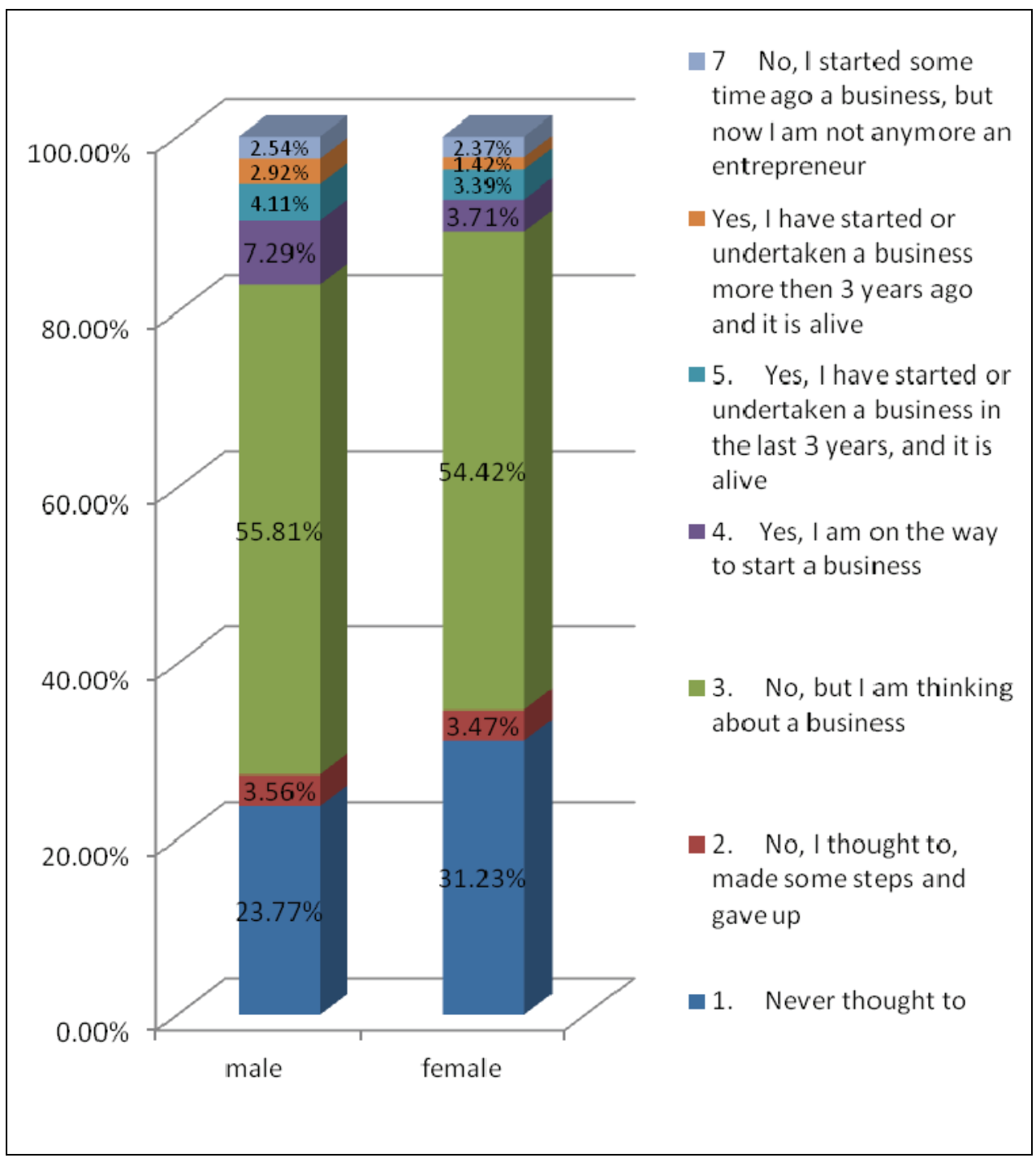

Fig. 5. Elan participant's entrepreneurial spirit by gender 


\section{References}

[1] Prof. Michael Porter; Competitive Advantage of Nations; Ed. The Free Press, 1990/ ISBN 0684-84147-9

[2] Prof. Michael Porter; On Competition; Ed. HBR 1998/ ISBN 0-87584-795-1

[3] Prof. Clayton M. Christensen; Disrupting Class (How disruptive innovation will change the World learns); Ed. Mc Grow Hill, 2008/ ISBN 978-0-07-159206-2

[4] Prof. Stephen R. Covey; The 8th Habit. From Effectiveness to Greatness; Ed,. Alfa, 2006/ISBN (10) 973-724-053-7

[5] Prof. Stephen R. Covey; The Seven Habits of Highly Effective People; Ed,. Alfa, 2011/ISBN 978-973-724-338-6

[6] Stephen M.R. Covey; The Speed of Trust; Ed. Free Press 2008/ ISBN 13:978-0-7432-9730-1

[7] Prof. Franz Josef Rademacher; Balance or Distruction; Ed. Oekosoziales Forum Europa 2004/ ISBN 3-200-00079-1

[8] Prof. Franz Josef Rademacher; Global Marshal Plan; Ed. Global Marshal Foundation 2004/ ISBN 3-9809723-0-5

[9] Jim Collins; Good to Great; Ed. Harper Business 2001/ ISBN 0-06-662099-6

[10] Peter F Drucker; People and Performance; Ed. HBR 2007/ ISBN 978-1-4221-2065-1

[11] Prof. Thomas L. Friedman; The World is Flat; Ed. Douglas \& Mc Intire 2004/ISBN 978-155365-175-8

[12] Hamel Gary \& C.K. Prahalad; Competing for the Future; Ed. HBR 1994/ ISBN 0-87584716-1

[13] Prof. Noam Chomsky; Hegemony or Survival; Ed. Owl Books 2003/ isbn 0-8050-7688-3

[14] Prof. Henry Chesbrough; Open Innovation (The new imperative for creating and profiting from Technology; Ed. HBS / ISBN 1-4221-0283-1

[15] Prof. Henry Chesbrough; Open Innovation (Researching a new paradigme); Ed. Oxford University Press 2008/ ISBN 978-0--19-929072-7

[16] Stuart Peters; National Systems of Innovation (Creatng high tech industries); Ed. Palgrave McMilan 2006/ ISBN-13: 978-1-4039-4614-0

[17] Jan Fagerberg, David C. Mowery, Richard R Nelson; The Oxford Handbook of Innovation; Ed Oxford University Press 2005 / ISBN 978-0-19-926455-1

[18] The Boston Consulting Group; On Strategy; Ed. John Wiley \& Sons 2006 /ISBN 978-0471-75722-1

[19] Richard H. K. Vietor; How Countries Compete (Strategy, structure, and government in the global economy); Ed. HBS 2007 / ISBN 978-1-4221-1035-5

[20] Robert Shapiro; Futurecast 2020 (A global vision of Tomorrow); Ed. Profile Books LTD 2008 / ISBN 978-1-86197-968-1

[21] Andrew Craine \& Dirk Matten; Business Ethics; Ed. Oxford University Press 2004/ ISBN 9780199284993

[22] http://europa.eu/press_room/pdf/complet_en_barroso__007_-_europe_2020__en_version.pdf

[23] http://www.proinno-europe.eu/inno-metrics/page/innovation-union-scoreboard2010

[24] http:/ / ec.europa.eu/research/innovationunion/index_en.cfm?section=competitiveness-report\&year $=2011$

[25] http://ec.europa.eu/research/innovation-union/pdf/innovation-unioncommunication_en.pdf 


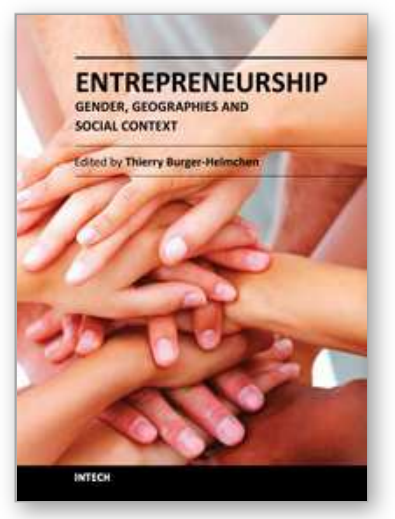

\author{
Entrepreneurship - Gender, Geographies and Social Context \\ Edited by Prof. Thierry Burger-Helmchen
}

ISBN 978-953-51-0206-9

Hard cover, 306 pages

Publisher InTech

Published online 14, March, 2012

Published in print edition March, 2012

Entrepreneurship is a main driver of economic growth and of social dynamics. However, some basic characteristics like the gender of the entrepreneur, the geographical location, or the social context may have a tremendous impact on the possibility to become an entrepreneur, to create a firm and to prosper. This book is a collection of papers written by an array of international authors interested in the question of entrepreneurship from a gender point of view (male vs female entrepreneurship), a geographical point of view (Africa, Europe, America and Latin America, Asia...) or a specific social context point of view (agricultural economy, farming or family business, etc.).

\title{
How to reference
}

In order to correctly reference this scholarly work, feel free to copy and paste the following:

Alexandru Borcea and Rosemari Fuica (2012). Does Romania Have a Chance to Join the Innovation Driven Economy?, Entrepreneurship - Gender, Geographies and Social Context, Prof. Thierry Burger-Helmchen (Ed.), ISBN: 978-953-51-0206-9, InTech, Available from: http://www.intechopen.com/books/entrepreneurshipgender-geographies-and-social-context/does-romania-have-a-chance-to-join-the-innovation-driven-economy-

\section{INTECH}

open science | open minds

\section{InTech Europe}

University Campus STeP Ri Slavka Krautzeka 83/A 51000 Rijeka, Croatia Phone: +385 (51) 770447 Fax: +385 (51) 686166 www.intechopen.com

\section{InTech China}

Unit 405, Office Block, Hotel Equatorial Shanghai No.65, Yan An Road (West), Shanghai, 200040, China 中国上海市延安西路65号上海国际贵都大饭店办公楼405单元 Phone: +86-21-62489820

Fax: +86-21-62489821 
(C) 2012 The Author(s). Licensee IntechOpen. This is an open access article distributed under the terms of the Creative Commons Attribution 3.0 License, which permits unrestricted use, distribution, and reproduction in any medium, provided the original work is properly cited. 